\title{
Analysis of AquaCrop Model for Potato Crop under Different Irrigation Levels
}

\author{
Datta B. Tayade ${ }^{1 *}$, Mahesh Kothari ${ }^{2}$, S.R. Bhakar ${ }^{3}$ and Manjeet Singh ${ }^{4}$ \\ PG Student, Department of Soil and Water Engineering, C.T.A.E, MPUAT, \\ Udaipur 313001, India \\ *Corresponding author
}

\begin{tabular}{|l|}
\hline Ke y w o r d s \\
AquaCrop, \\
Calibration, \\
Validation, Canopy, \\
Biomass, Yield
\end{tabular}

\section{Introduction}

Estimation of water requirement of crop is important for crop planning on farm and, for designing and monitoring irrigation projects. Prediction methods for crop water requirements are used owing to difficulty of obtaining accurate field measurements. Testing the accuracy of methods to estimate water requirement of crop under a new set of conditions is laborious and time consuming. Therefore, use of available technology and computer software with proper measures to suit the soil and land conditions may be a better option.

Accurate crop development models are important tools in evaluating the effects of 
water deficits on crop yield or productivity. Food and Agricultural Organization (FAO) of United Nations addresses this need by providing a yield response to water simulation model (AquaCrop) with limited sophistication. It simulates crop yield response to water, and is particularly suited to address conditions where water is a key limiting factor in crop production. AquaCrop is developed from revision of 'FAO Irrigation and Drainage Paper No. 33 Yield Response to Water' (Doorenbos and Kassam, 1979).The capacity of AquaCrop model in simulating the yield in response to water is proved by various researchers (Araya et al. 2010a, Heng et al., 2009; Stricevic et al., 2011; Abedinpour et al., 2012, Andarzian et al., 2011). The use of these models can assist in evaluating and reducing time intensive and expensive field tests (Whisler et al., 1986). Model results with regards to crop performance, management and yield estimates will help decision makers to decide which management system is suited best for a particular field, by estimating the yield and crop water productivity optimum.

Small-scale irrigation initiatives are expanding rapidly in Rajasthan. However, in many cases optimal yields are not being obtained despite the available water and required nutrient applications. Local stakeholders need an easy to use and decision support tool to assess irrigation water use and its impact on yield.

Potato (Solanum tuberosum L.) has emerged as fourth most important food crop in India after rice, wheat and maize. Potato belongs to the solanaceae family which includes peppers, eggplant, tomato and tobacco. It is a very sensitive crop to water stress and temperature. Potatoes have significant nutritional value and are rich in vitamins and minerals which are vital to human health. Hence, Indian vegetable basket is incomplete without Potato. It has been observed that during present trend of diversification from cereals to horticultural crops, shifting from wheat/ barley cultivation to potato cultivation is economically rewarding owing to comparative advantage of potato over other vegetable crops. Potato cultivation is highly adaptable to a wide variety of farming systems. With its short vegetative cycle and high yields within 100 days, it fits well into double cropping systems with rice, and is also suitable for inter cropping with maize and soy beans.

\section{Materials and Methods}

\section{Site description}

The study was carried out during the rabi season of 2017-2018 (Oct-Feb) at Plasticulture farm of College of Technology and Engineering, MPUAT, Udaipur Rajasthan. The study area is located between $24^{\circ} 35^{\prime} 31.5^{\prime \prime}$ to $24^{\circ} 35^{\prime} 31.3^{\prime \prime} \mathrm{N}$ latitude $73^{\circ} 44^{\prime} 18.2^{\prime \prime}$ to $73^{\circ} 44^{\prime} 21.1^{\prime \prime} \mathrm{E}$ longitude and at an altitude of $582.17 \mathrm{~m}$ above mean sea level. The study area comes under dry, sub-humid agro-climatic region. The average annual rainfall of $654.3 \mathrm{~mm}$, most of the rain received during the period of July to September. May is the hottest and December is the coolest month of the year. The maximum temperature goes as $32-44^{\circ} \mathrm{C}$ during summer and minimum as $2-15^{\circ} \mathrm{C}$ during winter months. The atmospheric humidity is high from June to October.The climatic data during the cropping period were obtained from Agrometeorological Observatory, Department of Soil and Water Engineering, MPUAT, Udaipur. The daily ETo was computed using the FAO-Penman-Monteith equation.The physical properties of soil analyzed include; texture (Sand - 66.75\%, Silt - 19.64\%, Clay $12.54 \%$ ), bulk density- $1.47 \mathrm{~g} \mathrm{cc}^{-1}$, field capacity (\% dry basis)- 18.67 , permanent wilting point (\% dry basis)- 4.92. Chemical characteristics of the soil at experimental site was observed as pH-7.64, Electrical conductivity- $1.38 \mathrm{dS} \mathrm{m}{ }^{-1}$, Organic carbon- 
$0.417 \%$, Total nitrogen- $100.21 \mathrm{Kg} \mathrm{ha}^{-1}$, Available phosphorous- $10.32 \mathrm{~kg} \mathrm{ha}{ }^{-1}$, Available potassium- $98.70 \mathrm{~kg} \mathrm{ha}^{-1}$.

\section{Experimental setup}

The field experiment was laid in a $3 \times 3$ factorial Randomised Complete Block Design with three mulch materials i.e. no-mulch $\left(\mathrm{M}_{1}\right)$, Black polyethylene mulch $\left(\mathrm{M}_{2}\right)$ and polypropylene woven mulch $\left(\mathrm{M}_{3}\right)$ with three irrigation levels constitutes $100 \% \mathrm{ETc}\left(\mathrm{I}_{1}\right)$, $80 \% \mathrm{ETc}\left(\mathrm{I}_{2}\right)$ and $60 \% \mathrm{ETc}\left(\mathrm{I}_{3}\right)$ with three replications. The irrigation levels were based on crop evapotranspiration (ETc) and irrigation was scheduled when it reaches a certain level of deficit.

\section{Description of Aquacrop model}

AquaCrop model is based on crop growth engine which is basically water driven, in which, the crop growth and production are driven by the amount of water used through consumptive use. The complexity of crop responses to water deficits led to the use of empirical production functions as the most practical option to assess crop yield response to water. Among the empirical function approaches, FAO Irrigation and Drainage Paper No. 33 (Doorenbos and Kassam, 1979) represented an important source to determine the yield response to water, in case of field, vegetable and tree crops, through the following equation:

$$
\left(1-\frac{\mathrm{Y}_{\mathrm{a}}}{\mathrm{Y}_{\mathrm{x}}}\right)=\mathrm{k}_{\mathrm{y}}\left(1-\frac{\mathrm{ET}_{\mathrm{a}}}{\mathrm{ETx}}\right) \ldots(3.1)
$$

Where,

$\mathrm{Y}_{\mathrm{x}}$ and $\mathrm{Y}_{\mathrm{a}}$ - Maximum and actual yield, $\mathrm{ET}_{\mathrm{x}}$ and $\mathrm{ET}_{\mathrm{a}}$ - Maximum and actual evapotranspiration, and

$\mathrm{k}_{\mathrm{y}} \quad-$ Crop yield factor

The changes described led to the following equation at the core of AquaCrop growth engine: Continuous revision of above relationship by FAO experts resulted in AquaCrop model. It differs from the main existing models for its balance between accuracy, simplicity and robustness. The conceptual framework, underlying principles and, distinctive component and features of AquaCrop are described by Steduto et al., (2009), while the structural details and algorithms are reported by Raes et al., (2009).

AquaCrop evolves from the previous Doorenbos and Kassam (1979) approach (Eq. 3.1) by separating (i) the ET into soil evaporation (E) and crop transpiration (Tr) and (ii) the final yield (Y) into biomass (B) and harvest index (HI). The separation of ET into soil evaporation (E) and crop transpiration (Tr) avoids the confounding effect of the nonproductive consumptive use of water (E). This is important especially during incomplete ground cover. The separation of final yield (Y) into biomass (B) and harvest index (HI) allows the distinction of the basic functional relations between environment and biomass (B) from those between environment and HI. These relations are in fact fundamentally different and their use avoids the confounding effects of water stress on biomass (B) and on harvest index (HI).

$\mathrm{B}=\mathrm{WP} \sum \mathrm{T}_{\mathrm{r}}$

where,

B - Biomass

$\mathrm{T}_{\mathrm{r}} \quad$ - crop transpiration, $\mathrm{mm}$ and

WP - water productivity parameter, $\mathrm{kgm}^{-2}$

The canopy represents the source for actual transpiration that gets translated in a proportional amount of biomass produced through the water productivity parameter (WP) (Eq. 3.2). The harvestable portion of such biomass (yield) is then determined through harvest index (HI) as below (Eq. 3.3).

$\mathrm{Y}=\mathrm{HI} \times \mathrm{B}$ 
Even though AquaCrop uses HI parameter, it does not calculate the separation of biomass into various organs (e.g. leaves, roots, etc.), i.e., biomass production is decoupled from canopy expansion and root deepening.

\section{Calibration and validation processes}

Part of the obtained field data i.e. data for full irrigation treatment $\left(100 \% \mathrm{ET}_{\mathrm{c}}\right.$ under nonmulch $-\mathrm{T}_{1}$ ) was used for calibration of the model, while the remaining data of remaining treatments was used to validate the model. AquaCrop version 6.0 was used in the study.

The model was calibrated and validated by varying following parameters manually: a) Canopy cover i.e., initial canopy cover (CCo), mode of planting, canopy size of planted seedling, maximum canopy cover, plant density, canopy decline, day 1 to recovery, day 1 to maximum canopy, senescence, harvest, root system and maximum effective depth. b) Harvest index. The potato yield (Y) and biomass (B) were simulated for different treatments using the calibrated model.

\section{Model performance}

In addition to qualitative determination with graphical displays using observed and simulated data set, the model simulation results were evaluated quantitatively using various statistical measures described below. Various performance measures were used in reference to the conclusion of Yapo et al., (1998) that any single performance measure may not adequately measure the ways in which model fails to match the important characteristics of target data. In accordance to the recommendation of ASCE (1993) task committee Nash Sutcliffe coefficient and a dimensionless statistical measure i.e. coefficient of residual mass was used to judge the performance of the model.

\section{a) Nash-Sutcliffe coefficient of efficiency}

Nash-Sutcliffe coefficient of efficiency $\left(\mathrm{R}^{2}{ }_{\mathrm{NS}}\right)$ is used to assess predictive power of hydrological models. $\mathrm{R}_{\mathrm{NS}}^{2}$ is described by following formula (Nash and Sutcliffe, 1970).

$$
\mathrm{R}_{\mathrm{NS}}^{2}=1-\frac{\Sigma\left(\mathrm{Q}_{0}-\mathrm{Q}_{\mathrm{S}}\right)^{2}}{\Sigma\left(\mathrm{Q}_{0}-\mathrm{Q}_{\mathrm{av}}\right)^{2}}
$$

Where,

Qo - Observed values

$\mathrm{Q}_{\mathrm{s}} \quad$ - Simulated values

$\mathrm{Q}_{\mathrm{av}} \quad$ - Mean of observed values

Nash-Sutcliffe coefficient of efficiency can range from $-\square$ to $1 . R_{N S}^{2}$ value of 1 therefore indicates perfect fit. An efficiency of zero indicates that the model predictions are as accurate as the mean of observed data. Closer the model efficiency to 1 , more accurate is the model. Model efficiency less than 0.7 correspond to a very poor fit (Coulibaly et al., 2000).

\section{b) Coefficient of residual mass}

Coefficient of Residual Mass (CRM) is dimensionless statistical performance criteria as described below.

$\mathrm{CRM}=\frac{\sum_{\mathrm{i}=1}^{\mathrm{n}} \mathrm{o}_{\mathrm{i}}-\sum_{\mathrm{i}=1}^{\mathrm{n}} \mathrm{s}_{\mathrm{i}}}{\sum_{\mathrm{i}=1}^{\mathrm{n}} \mathrm{o}_{\mathrm{i}}}$

Where,

$\mathrm{O}_{\mathrm{i}} \quad$ - Observed value at time $\mathrm{i}$

$\mathrm{S}_{\mathrm{i}} \quad$ - Simulated value at time i

This criterion indicates the overall under or over-estimation of the ordinates. For a perfect model, the value of CRM is zero. A positive value of CRM indicates the tendency of model to underestimate the observed ordinates, whereas the negative value indicates a tendency to overestimate the observed ordinates 


\section{Results and Discussion}

\section{Calibration of AquaCrop model}

AquaCrop model was calibrated for the period from $13^{\text {th }}$ October 2017 to $19^{\text {th }}$ February 2018 i.e.crop period, using field days after sowing for full irrigation treatment (i.e. irrigation scheduling at $100 \% \mathrm{ET}_{\mathrm{c}}$ under non-mulch $\mathrm{T}_{1}$ ). To judge the performance of model, observed values of model parameters i.e. canopy cover (CC), biomass and yield of potato were compared with simulated outputs.

From Table 1, it is observed that both the observed and simulated canopy cover percentage increase gradually as the day of sowing increases up to a maximum period of crop development. The result also shows that the observed canopy cover percentage attained its maximum at 80 days after sowing while the simulated canopy cover percentage reached its maximum at 80 days after sowing. Potato crop is estimated to attain mid-season stage at 55 days after sowing up to 100 days after sowing according to FAO paper No.56. Result also shows that there is close match between observed and simulated canopy cover. It is supported by high value of $\mathrm{R}_{\mathrm{NS}}^{2}(0.90)$. Another statistical parameter i.e. Coefficient of Residual Mass (CRM) having value as 0.141 , indicates that the model overestimates the canopy cover. The canopy cover was overestimated by model particularly during 30 to 130days after sowing i.e. during development stage. But, the scatter plot clears that as the canopy cover nearly lie on 1:1 line, there is no consistent over or under estimation. For harvesting index of $72.54 \%$, the model predicted yield was 8.85 tha $^{-1}$ and biomass 12.20 tha $^{-1}$ (Fig. 1 and 4).

Cumulative biomass was observed as $8.13 \mathrm{t}$ $\mathrm{ha}^{-1}$ for calibration period and the model predicted cumulative biomass was 12.20 tha $^{-1}$. Nash Sutcliffe coefficient $\left(\mathrm{R}^{2}{ }_{\mathrm{NS}}\right)$ as 0.81 indicates that the observed and simulated biomass was closely matched. Coefficient of residual mass as -0.427 indicated that the model slightly overestimates the biomass. The simulated cumulative biomass at 20 days after sowing was underestimated but the other simulation cumulative results at 40,60, 80 and 100 days after sowing were overestimated. On average, the model overestimated the biomass along the growth stages (Table 1). Figure 2 shows comparison of observed and simulated biomass. The result also indicates that the cumulative observed and simulated biomass is statistically correlated. The $\mathrm{R}^{2}{ }_{\mathrm{NS}}(0.81)$ indicates that there was a strong positive correlation between the observed and simulated biomass values. AquaCrop model was able to simulate the total biomass yield as indicated by high correlation $\left(\mathrm{R}^{2}{ }_{\mathrm{NS}}=0.81\right)$ and $\mathrm{CRM}$ with value of -0.427 indicating model overestimate the biomass. This result is in conformity with Berti et al., (2014) who also explained, the model predicted biomass values at harvest quite well with the calculated values of statistic indices, RMSE and $\mathrm{R}^{2}$ were $0.6 \mathrm{t}$ $\mathrm{ha}^{-1}$, and 0.95 , respectively

Potato tuber yield was observed as 23.2tha ${ }^{-1}$ for calibration period. For harvesting index of $63 \%$, the model predicted yield was $23.38 \mathrm{t}$ ha $^{-1}$ (Table 1). Nash Sutcliffe coefficient $\left(\mathrm{R}_{\mathrm{NS}}^{2}\right)$ as 0.98 indicates that the observed and simulated yield was closely match. Coefficient of residual mass as 0.050 indicated that the model slightly underestimates the yield. The simulated yield at 20 days after sowing with highly underestimated above $50 \%$ but the other simulation results at 40, 80, and 100 days after sowing were less the $10 \%$ underestimated except for the period of 60 days after sowing which was more than $10 \%$ underestimated and the final yield at harvest was slightly overestimated by less than $10 \%$. On an average, the model underestimated the yield along the growth stages as shown in Figure 3. Above results showed that the model calibration was satisfactory as the observed and simulated values of canopy cover, 
biomass and potato yield matched well. Also $\mathrm{R}_{\mathrm{NS}}^{2}$ and CRM statistics were acceptable. Hence, the AquaCrop model setup was considered as calibrated. This result was in agreement with Bitri et al., (2014) who reported potato tuber yield was adequately simulated by the model with the performance evaluation of RMSE $\left(0.27 \mathrm{t} \mathrm{ha}^{-1}\right)$, normalized RMSE (5\%), E (0.97) and $\mathrm{R}^{2}(0.95)$. Calibrated model parameters are presented in Table 1.

Table.1 Comparison of observed and simulated canopy cover, cumulative biomass and yield of potato crop during calibration

\begin{tabular}{|c|c|c|c|c|c|c|c|}
\hline \multirow{2}{*}{$\begin{array}{l}\text { Day } \\
\text { after } \\
\text { sowing }\end{array}$} & \multicolumn{2}{|c|}{ Canopy cover $(\%)$} & \multirow{2}{*}{$\begin{array}{l}\text { Day } \\
\text { after } \\
\text { sowing }\end{array}$} & \multicolumn{2}{|c|}{$\begin{array}{c}\text { Cumulative biomass, } \\
\qquad \text { t ha }^{-1}\end{array}$} & \multicolumn{2}{|c|}{$\begin{array}{c}\text { Cumulative yield, } \\
\text { t ha }^{-1}\end{array}$} \\
\hline & Observed & Simulated & & Observed & Simulated & Observed & Simulated \\
\hline 20 & 1.5 & 0.75 & \multirow{2}{*}{0} & \multirow{2}{*}{0.00} & \multirow{2}{*}{0.00} & \multirow{2}{*}{0.00} & \multirow{2}{*}{0.00} \\
\hline 25 & 7.7 & 6.4 & & & & & \\
\hline 32 & 19.3 & 25.1 & \multirow{2}{*}{20} & \multirow{2}{*}{0.37} & \multirow{2}{*}{0.12} & \multirow{2}{*}{0.02} & \multirow{2}{*}{0.09} \\
\hline 39 & 27.4 & 33.3 & & & & & \\
\hline 46 & 39.2 & 48.1 & \multirow{2}{*}{40} & \multirow{2}{*}{1.03} & \multirow{2}{*}{1.56} & \multirow{2}{*}{0.78} & \multirow{2}{*}{1.20} \\
\hline 53 & 52.6 & 70.5 & & & & & \\
\hline 60 & 76.4 & 85.4 & \multirow{2}{*}{60} & \multirow{2}{*}{2.13} & \multirow{2}{*}{3.22} & \multirow{2}{*}{1.62} & \multirow{2}{*}{2.40} \\
\hline 67 & 82.3 & 90.2 & & & & & \\
\hline 74 & 89.1 & 93.8 & \multirow{2}{*}{80} & \multirow{2}{*}{3.43} & \multirow{2}{*}{4.75} & \multirow{2}{*}{2.85} & \multirow{2}{*}{4.04} \\
\hline 81 & 92.8 & 97.8 & & & & & \\
\hline 88 & 88.5 & 92.8 & \multirow{2}{*}{100} & \multirow{2}{*}{6.23} & \multirow{2}{*}{8.58} & \multirow{2}{*}{4.27} & \multirow{2}{*}{5.25} \\
\hline 95 & 83.7 & 90.6 & & & & & \\
\hline 102 & 78.1 & 88.7 & \multirow{3}{*}{130} & 813 & 1220 & 570 & 885 \\
\hline 116 & 73.8 & 85.8 & & 0.15 & 12.20 & 5.10 & $0.0 J$ \\
\hline 125 & 70.4 & 82.6 & & & & & \\
\hline $\mathbf{R}_{\text {NS }}^{2}$ & & 90 & $\mathbf{R}_{\mathrm{NS}}^{2}$ & & & & \\
\hline CRM & & 141 & CRM & & 427 & & 132 \\
\hline
\end{tabular}

Fig.1 Scatter plot of observed and simulated canopy cover for calibration period
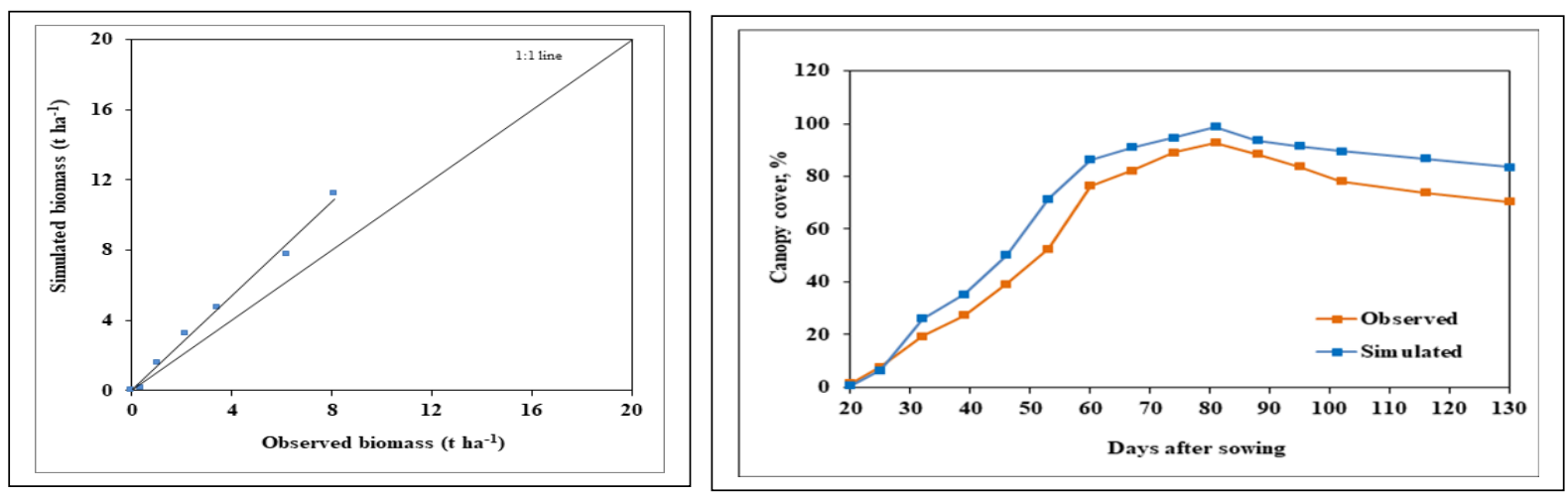
Fig.2 Scatter plot of observed and simulated biomass for calibration period
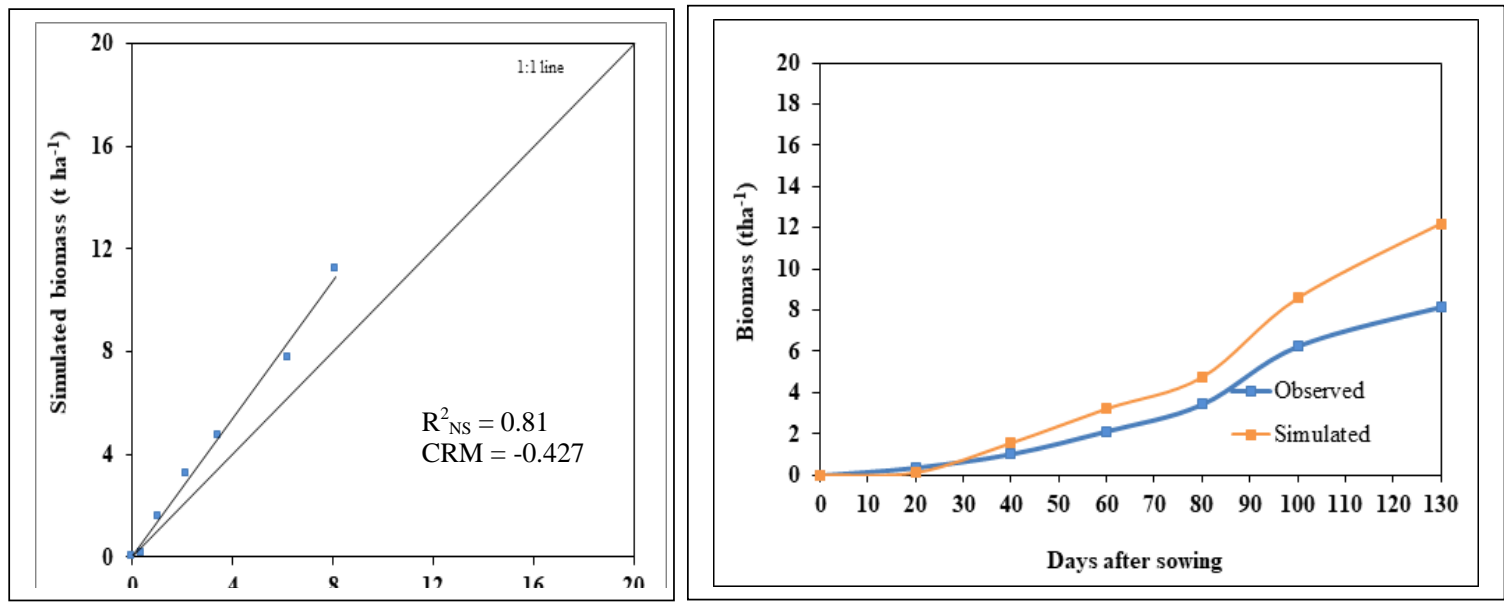

Fig.3 Scatter plot of observed and simulated yield for calibration period
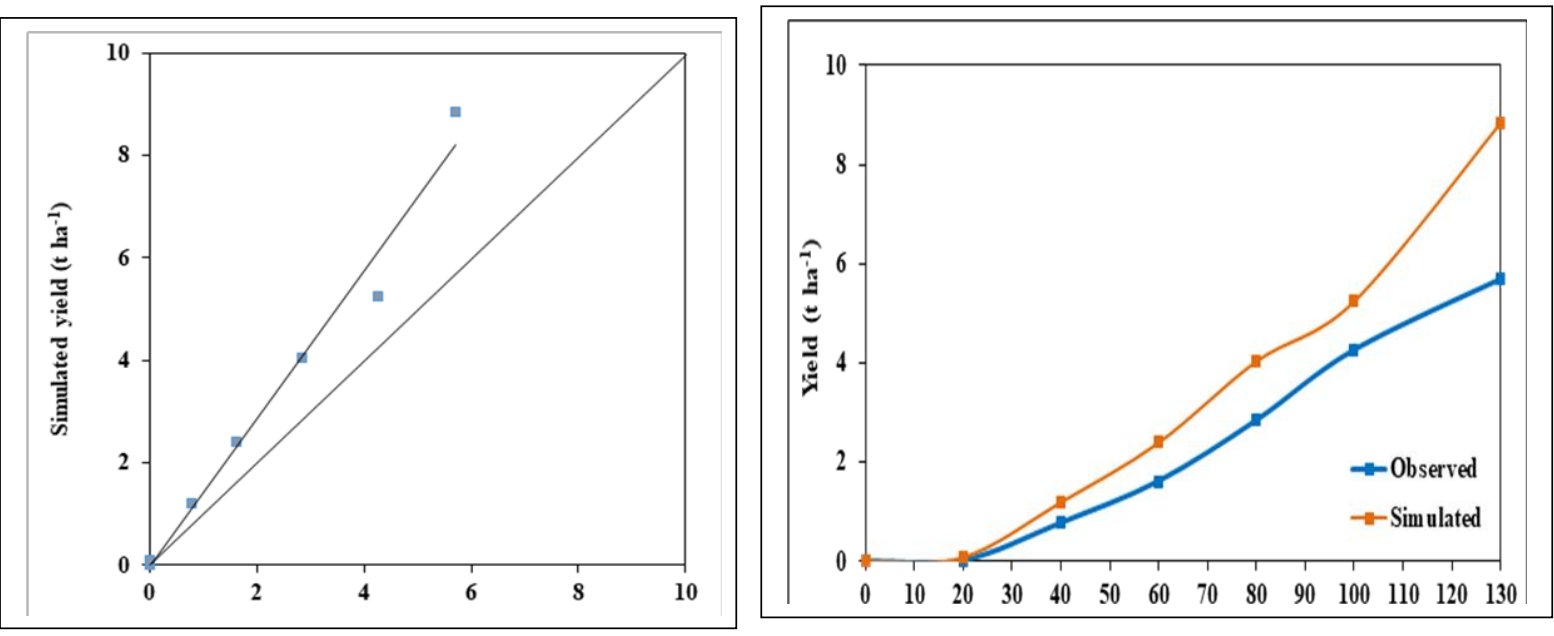

Fig.4 Scatter plot of observed and simulated Biomass and Yield for validation
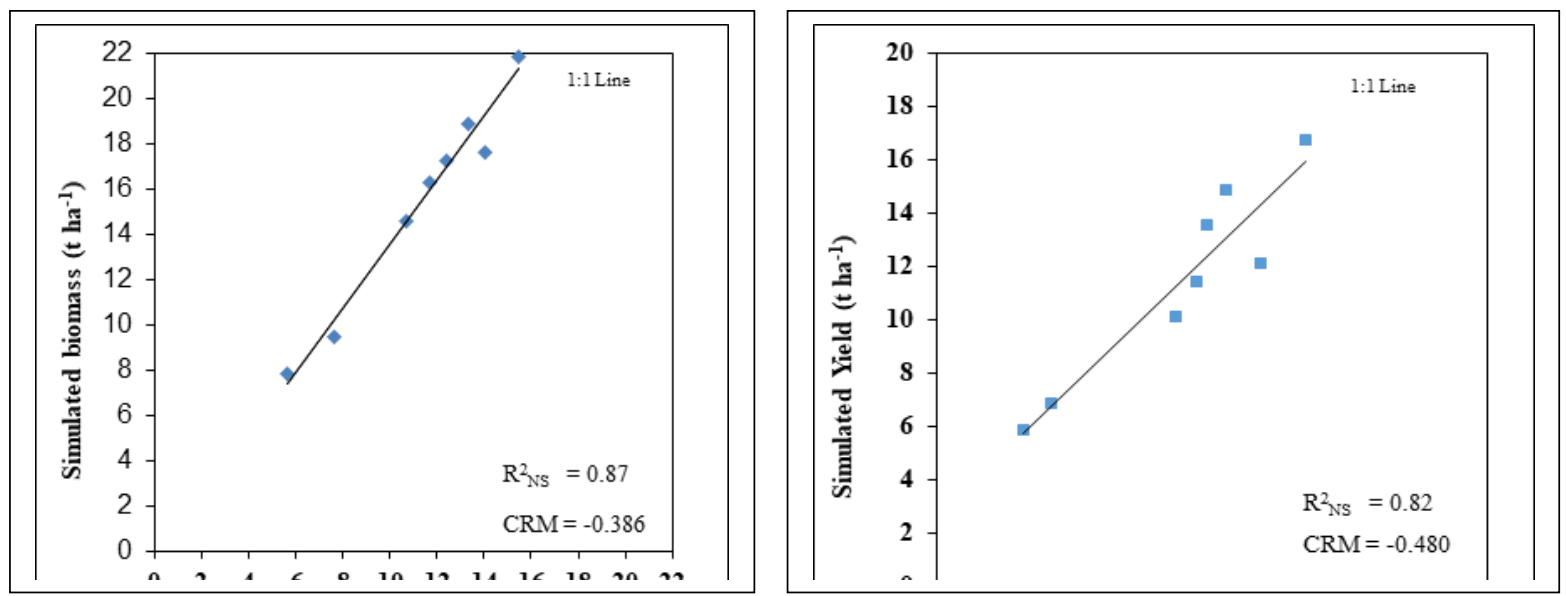


\section{Validation}

The observed biomass varied between 5.65 and $15.49 \mathrm{t} \mathrm{ha}^{-1}$, whereas observed yield of potato varied between 3.17 to $13.37 \mathrm{t} \mathrm{ha}^{-1}$. Similarly, the simulated biomass varied between $7.83 \mathrm{t} \mathrm{ha}^{-1}$ and $21.85 \mathrm{t} \mathrm{ha}^{-1}$, whereas simulated yield of potato tuber varied between $6.22 \mathrm{t} \mathrm{ha}^{-1}$ to $17.72 \mathrm{t} \mathrm{ha}^{-1}$. Nash Sutcliffe coefficient $\left(\mathrm{R}^{2}{ }_{\text {NS }}\right)$ values were found as 0.87 for biomass and 0.82 for potato yield which shows close match between observed and simulated biomass and yield, respectively. CRM values for biomass and yield were found as -0.386 and -0.480 , indicates that model overestimates the biomass and yield respectively during validation.

In conclusion, AquaCrop model output i.e. variation in transpiration, crop canopy cover, root zone depletion in reference to field capacity, production output shows that the transpiration matched with that of full irrigation schedule (i.e. $80 \% \mathrm{ET}_{\mathrm{c}}$ ) throughout the growing period. The canopy cover percentage started to develop gradually from 30 days after sowing and reached to maximum at 80 days after sowing and remains constant from 80 to 110 days after sowing and gradually started declining till final harvest. During calibration $\mathrm{R}^{2}{ }_{\text {Nsvaluesfor Canopy cover, Biomass and }}$ Yield were found as 0.90, 0.81 and 0.80respectively.Also, CRM values for Canopy cover, Biomass and Yieldwere found as $-0.141,-0.427$ and -0.432 respectively. Hence it can be concluded that during calibration model overestimates canopy cover, biomass and yield. During validationR $^{2}$ NS values for biomass and yield were found as 0.87 and 0.82respectively. Also, CRM values for biomass and yield were found as -0.386 and -0.480 respectively, which concluded that model overestimates the biomass and yield.

\section{References}

Abedinpour M., Sarangi A., Rajput T., B., S., Singh, Man, Pathak H., Ahmad T. 2012. Performance evaluation of AquaCrop model for maize crop in a semi-arid environment. Agricultural Water Management, 110: 55-66.

Andarzian, A., Bannayan, M., Steduto, P., Mazraeh, H., Barati, M.E., Barati, M.A. and Rahnama A. 2011. Validation and testing of the AquaCrop model under full and deficit irrigated wheat production in Iran. Agricultural Water Management. 100: 1-8.

Araya, A., Habtu, S., Hadgu, K. M., Kebede, A. and Dejene, T. 2010a. Test of AquaCrop model in simulating biomass and yield of water deficient and irrigated barley (Hordeum vulgare). Agricultural Water Management. 97: 1838-1846.

ASCE Task Committee on Definition of Criteria for Evaluation of Watershed Models of Watershed Management Committee, Irrigation and Drainage Division (1993). Criteria for evaluation of watershed models. Journal of Irrigation and Drainage. Engineering, 119(3): 429-442

Bitri, M. and Grazhdani,S. 2015.Validation of Aqua Crop model in the simulation of sugar beet production under different water regimes in southeastern Albania. International $\mathrm{J}$ Engineering Science and Innovative Technology,4(6) : 171-181.

Coulibaly, P., Anctil, F., and Bobee, B. 2000. Daily reservoir inflow forecasting using artificial neural networks with stopped training approach. Journal of Hydrology, 230: 244-257.Doorenbos J, Kassam A. H., and Bentvelsen C., I., M. 1979. Yield response to water, Rome. Food and Agriculture Organization of the United Nations. 
Heng, L. K., Hsiao, T., Evett, S., Howell, T., and Steduto, P. 2009. Validating the FAO AquaCrop model for irrigated and water deficient field maize. Agronomy Journal.101: 488-498.

Nash, J. E., and Sutcliffe, J. V. 1970. River flow forecasting through conceptual models part 1 a discussion of principles. Journal of Hydrology. 10: 282-290.

Raes, D., Steduto, P., Hsiao, T. C. and Fereres, E. 2009.AquaCropThe FAO Crop Model to Simulate Yield Response to Water: II. Main Algorithms and Software Description. Agronomy J., 101 (3): 438.

Steduto P., Hsiao T. C., Raes D., and Fereres E. 2009. AquaCrop-The FAO crop model to simulate yield response to water: I. Concepts and Underlying
Principles. Agron. J., 101(3): 426-437.

Stricevic, R., Cosic, M., Djurovic, N., Pejic, B. and Maksimovic, L. 2011. Assessment of the FAO AquaCrop model in the simulation of rainfed and supplementally irrigated maize, sugar beet and sunflower. Agricultural Water Management.98: 161- 162.

Whisler, F. D., Acock, B., Baker, D. N., Fye, R. E., Hodges, H. F., Lambert J. R., Lemmon H. E., Mc. Kinion, J.M., and Reddy, V. R. 1986. Crop simulation models in agronomic systems. Adv. Agron.40: 141-208.

Yapo, P. O., Gupta, H. V., and Sorooshian, S. 1998. Multi-objective global optimization for hydrologic models, J. Hydrol., 204: 83-97.

\section{How to cite this article:}

Datta B. Tayade, Mahesh Kothari, S.R. Bhakar and Manjeet Singh. 2018. Analysis of AquaCrop Model for Potato Crop under Different Irrigation Levels. Int.J.Curr.Microbiol.App.Sci. 7(08): 4770-4778. doi: https://doi.org/10.20546/ijcmas.2018.708.501 